\section{FIRST RECORD OF THE GREY REEF SHARK CARCHARHINUS AMBLYRHYNCHOS, (BLEEKER, 1856) (CARCHARHINIFORMES: CARCHARHINIDAE) FROM THE LAKSHADWEEP} SEA, INDIA

K.V. Aneesh Kumar ${ }^{1}$, S. Paresh Khanolkar ${ }^{2}$, P. Pravin ${ }^{3}$, B. Meenakumari ${ }^{4}$ \& E.V. Radhakrishnan ${ }^{5}$

${ }^{1,2,3}$ Central Institute of Fisheries Technology, Matsyapuri P.O, Willington Island, Cochin, Kerala 682029, India

${ }^{4}$ Indian Council of Agricultural Research, Krishi Anusandhan Bhavan-II, New Delhi 110012, India

${ }^{5}$ Central Marine Fisheries Research Institute, Cochin, Kerala 682018, India ${ }_{1}^{1}$ menoncift@gmail.com (corresponding author), ${ }^{2}$ kh paresh@rediffmail.com, ${ }^{3}$ pravinp2005@gmail.com, ${ }^{4}$ meenakumarib@gmail.com, ${ }^{5}$ evrkrishnan@gmail.com

Grey Reef Shark Carcharhinus amblyrhynchos (Carcharhiniformes: Carcharhinidae) is a widely distributed requiem shark in the Pacific Ocean, and has an extensively scattered distribution in the Indian Ocean (Compagno 1984; William 2006). Indian elasmobranch fishery is one of the largest in the world (Vannuccini 1999) but information available on this species is very scanty (Raje et al. 2007). Pillai \& Parakal (2000) and Joshi et al. (2008) have reported the presence of $C$. amblyrhynchos landings from Indian waters. Grey Reef Shark is a typical 'reef shark', found in clear tropical waters often from 10-50 $\mathrm{m}$ around coral reefs, in shallow water near coral slopes of islands and continents particularly near dropoffs, passes of fringing reefs and relatively common in atolls (Wetherbee et al. 1997; Economakis \& Lobel 1998). The IUCN Red List of Threatened Animals categorizes C. amblyrhynchos as Near Threatened (Smale 2009), possibly due to its restricted habitat, site fidelity, inshore distribution, small litter size, and relatively late age at maturity, along with increasing fishing pressure.

Information available on the diversity and abundance of carcharhinid sharks in Indian waters is very meager though they contribute a major portion of the fishery. No scientific information

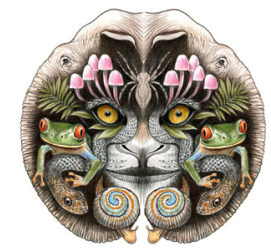

ISSN

Online 0974-7907 Print 0974-7893

\section{OPEN ACCESS} is available on the presence of Grey Reef Shark in Lakshadweep waters which are known for coral reef biodiversity. In this paper, evidence for the occurrence of C. amblyrhynchos in Lakshadweep Sea is presented.

A female Grey Reef Shark C. amblyrhynchos was landed by fishermen from longline operation off Agatti Island in Lakshadweep Sea on 25 November 2010 (Image 1). The shark was caught by 3.4 Sun Japanese tuna hook and the location of capture was recorded as $10^{\circ} 47^{\prime} \mathrm{N} \&$ $72^{\circ} 09^{\prime} \mathrm{E}$ (Image 2). The morphometric measurements of the shark were made to the nearest millimeter and weight was measured to the nearest gram. The species identification was based on Compagno (1984).

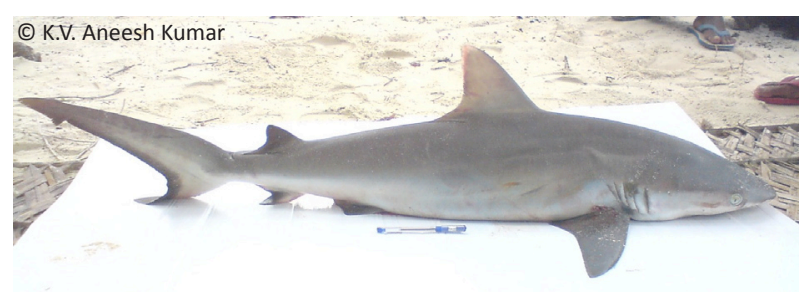

Image 1. Grey Reef Shark Carcharhinus amblyrhynchos (TL 126cm)

DOI: http://dx.doi.org/10.11609/JoTT.03223.987 | ZooBank: urn:Isid:zoobank.org:pub:076AC7CE-BF02-489E-9649-3B05A502D64E

Editor: E. Vivekanandan, Central Marine Fisheries Research Institute, Chennai, India.

Date of publication: 26 January 2013 (online \& print)

Manuscript details: Ms \# 03223 | Received 29 May 2012| Final received 27 October 2012 | Finally accepted 08 December 2012

Citation: K.V.A. Kumar, S.P. Khanolkar, P. Pravin, B. Meenakumari \& E.V. Radhakrishnan (2013). First Record of the Grey Reef Shark Carcharhinus amblyrhynchos, (Bleeker, 1856) (Carcharhiniformes: Carcharhinidae) from the Lakshadweep Sea, India. Journal of Threatened Taxa 5(1): 3580-3582; doi:10.11609/JoTT. 03223.987

Copyright: @ Kumar et al. 2013. Creative Commons Attribution 3.0 Unported License. JoTT allows unrestricted use of this article in any medium, reproduction and distribution by providing adequate credit to the authors and the source of publication.

Funding: The financial assistance received from NAIP, ICAR, Govt. of India is gratefully acknowledged.

Competing Interest: None.

Acknowledgements: The authors are grateful for the encouragement given by the Director, CIFT, Kochi, India during the course of this work. 

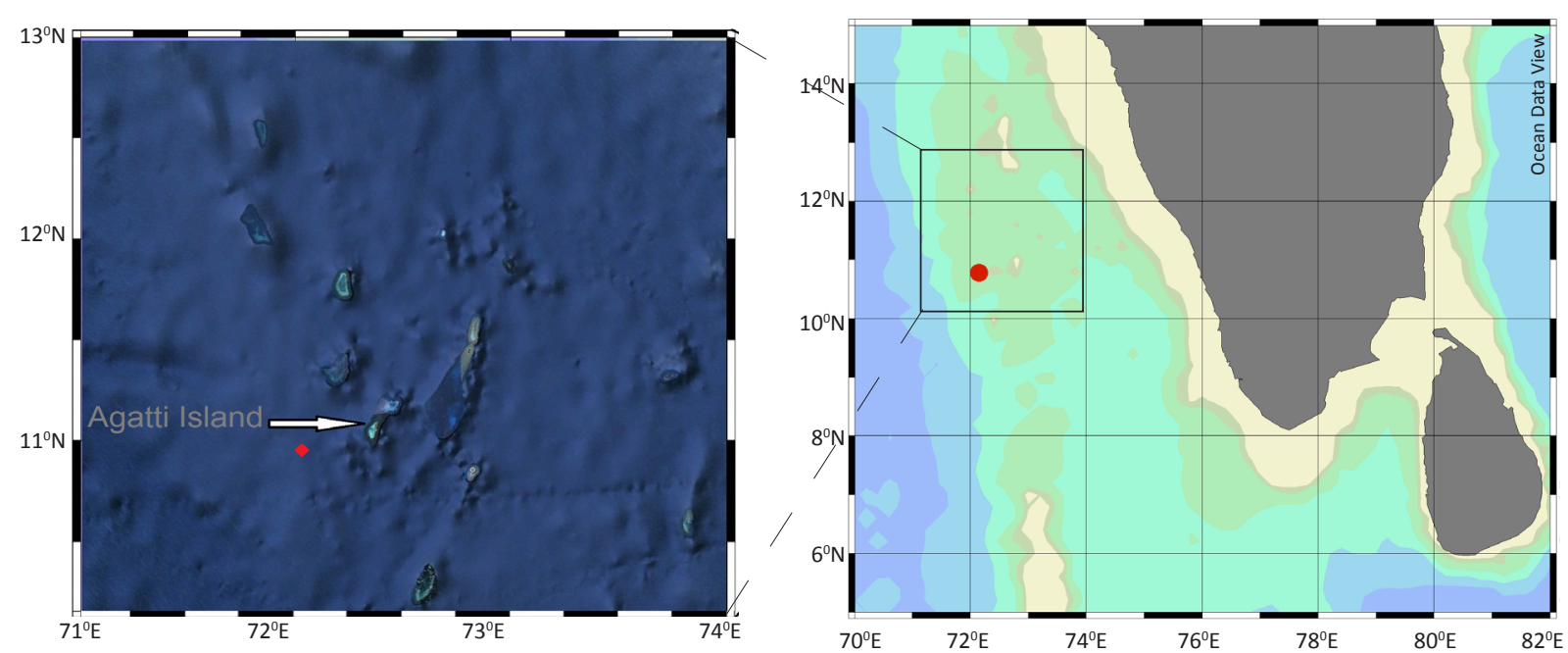

Image 2. The location of capture of a Grey Reef Shark from the Lakshadweep Sea.

\section{Results and Discussion}

The morphometric measurements of the specimen are given in Table 1. The total length (TL) of the specimen was $126 \mathrm{~cm}$ and standard length (SL) was $106 \mathrm{~cm}$. The Grey Reef Shark is a moderately stocky species, distributed in the coastal and pelagic waters of IndoPacific. Carcharhinus amblyrhynchos can be identified by the following characters: dusky grey color above and white below; first dorsal fin irregularly to prominently white edged (Image 3); posterior margin of the caudal fin with a conspicuous broad black margin; pectoral, second dorsal, anal and pelvic fins with blackish or dusky tips and prominent blackish margin (Image 4). The First dorsal fin is moderately large and semifalcate with a narrowly pointed apex. Second dorsal fin is moderately large and high. Pectoral fins falcate. Snout fairly long and broadly rounded. Eyes are round and fairly large. Upper labial furrows short and inconspicuous. Inter dorsal ridge absent. Upper teeth are narrow and serrated (Image 5). The species inhabits continental and insular shelves preferably on coral reefs and in shallow lagoons. The area from where the specimen is reported was near the coral ridge in Lakshadweep Sea. Present record is the first report of Carcharhinus amblyrhynchos from the Lakshadweep Archipelago.

\section{REFERENCES}

Compagno, L.J.V. (1984). Sharks of the world. An annotated and illustrated catalogue of shark species known to date. Part 2-Carcharhiniformes. FAO Fish Synopsis 4(125): 251-655.

Economakis, A.E. \& P.S. Lobel (1998). Aggregation behavior of the Grey Reef Shark Carcharhinus amblyrhynchos, at Johnston Atoll, Central
Table 1. Morphometric measurements of Carcharhinus amblyrhynchos (female, $126 \mathrm{~cm} \mathrm{TL}$ ) from Lakshadweep Sea

\begin{tabular}{|l|c|c|}
\hline Measurements & cm & \% of total length \\
\hline Total length & 126 & 100.0 \\
\hline Standard length & 106 & 84.1 \\
\hline Snout to eye & 11 & 8.7 \\
\hline Snout to pectoral & 33.5 & 26.6 \\
\hline Snout to first dorsal & 43 & 34.1 \\
\hline Snout to pelvic & 76.5 & 60.7 \\
\hline Eye diameter & 2.5 & 2.0 \\
\hline Eye to pectoral & 20 & 15.9 \\
\hline Between dorsal bases & 25.2 & 20.0 \\
\hline Pectoral to pelvic & 34.5 & 27.4 \\
\hline Pelvic to anal & 8.5 & 6.7 \\
\hline Pre first dorsal length & 43 & 34.1 \\
\hline First dorsal base & 13 & 10.3 \\
\hline First dorsal anterior margin & 17 & 13.5 \\
\hline Second dorsal base & 4 & 3.2 \\
\hline Pectoral anterior margin & 24 & 19.0 \\
\hline Pectoral base & 5.5 & 6.7 \\
\hline Dorsal caudal margin & 19.5 \\
\hline Anal base & & \\
\hline Preventral caudal margin & 11 & 27.4 \\
\hline Lower postventral caudal margin & 19 & \\
\hline
\end{tabular}




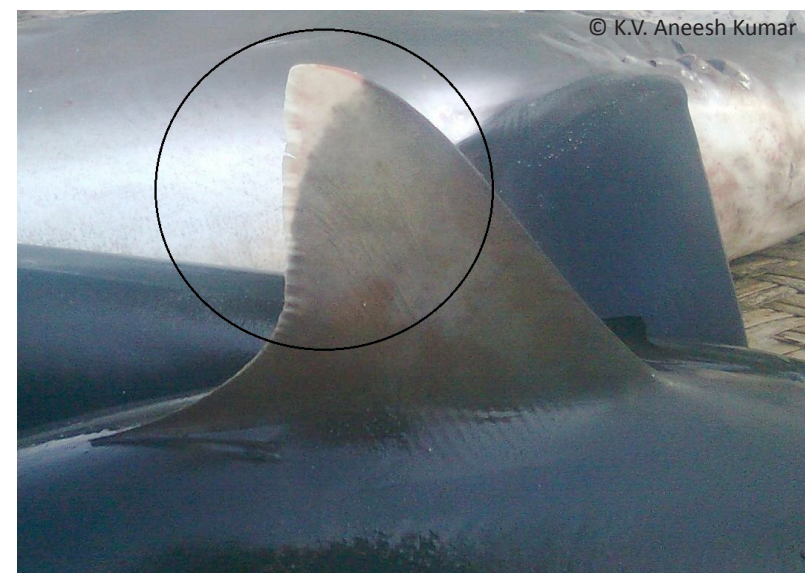

Image 3. Irregular white edge of the first dorsal fin margin

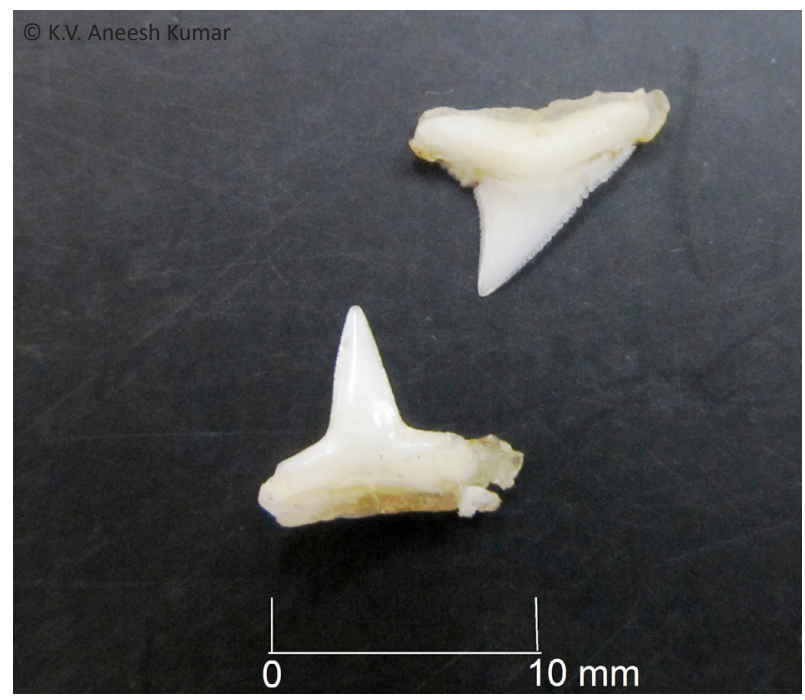

Image 5. Upper and lower teeth

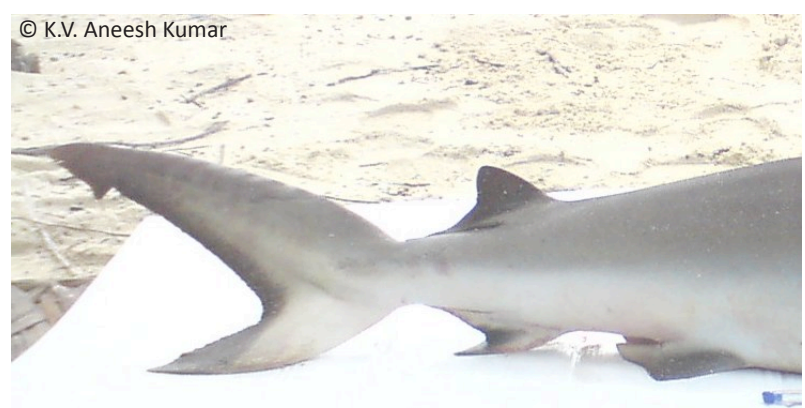

Image 4. Blackish margins in the pelvic, second dorsal, anal and caudal fins

Pacific Ocean. Environmental Biology of Fishes 51: 129-139. IUCN (2011). IUCN Red List of Threatened Species. Version 2011. www. iucnredlist.org. (Downloaded on 18 November 2011).

Joshi, K.K., K. Balachandran \& S.G. Raje (2008). Changes in the shark fishery at Cochin. Journal of Marine Biological Association India 50 (1): 103-105.

Pillai, P.P. \& B. Parakal (2000). Pelagic Sharks in the Indian Seas-their Exploitation, Trade, Management and Conservation. Central Marine Fisheries Research Institute Special publication 70: 1-95.

Raje, S.G., S. Sivakami, G. Mohanraj, P.P. Raju \& K.K. Joshi (2007). An atlas on the elasmobranch fishery resources of India. CMFRI Special Publication 95: 253pp.

Smale, M.J. (2009). Carcharhinus amblyrhynchos. In: IUCN 2012. IUCN Red List of Threatened Species. Version 2012.2. <www.iucnredlist. org>. Downloaded on 17 January 2013.

Vannuccini, S. (1999). Shark utilization, marketing and trade. FAO Fisheries Technical Paper 398.

Wetherbee, B.M., G.L. Crow \& C.G. Lowe (1997). Distribution, reproduction and diet of the gray reef shark Carcharhinus amblyrhynchos in Hawaii. Marine Ecology Progress Series 151: 181-189.

William, D.R. (2006). Abundance, demography and population structure of Grey Reef Shark (Carcharhinus amblyrhinchos) and the white tip Reef Shark (Triaenodon obesus) (Fam. Carcharhinidae). PhD Thesis, James Cook University, Australia, 197pp. 